\title{
A nyaki verőér-szúlkületes betegek ellátási irányelveinek különbségei Európa különböző országaiban
}

\author{
Mihály Zsuzsanna dr. ${ }^{1}$ - Fontanini Danielle Mariastefano dr. ${ }^{1}$ \\ Sándor Ágnes Dóra dr. ${ }^{2}$ - Dósa Edit dr. ${ }^{3}$ - Lovas Gábor dr. ${ }^{4}$ \\ Kolossváry Endre dr. ${ }^{5}$ - Kovács Illés $d r{ }^{6}{ }^{6}$ István Lilla dr. ${ }^{6}$ \\ Entz László dr. ${ }^{1}$ - Sótonyi Péter jr. dr. ${ }^{1}$
}

\author{
${ }^{1}$ Semmelweis Egyetem, Általános Orvostudományi Kar, Városmajori Szív- és Érgyógyászati Klinika, \\ Érsebészeti és Endovaszkuláris Tanszék, Budapest \\ ${ }^{2}$ Semmelweis Egyetem, Általános Orvostudományi Kar, Aneszteziológiai és Intenzív Terápiás Klinika, Budapest \\ ${ }^{3}$ Semmelweis Egyetem, Általános Orvostudományi Kar, Városmajori Szív- és Érgyógyászati Klinika, \\ Intervenciós Radiológia Tanszék, Budapest \\ ${ }^{4} J a h n$ Ferenc Dél-pesti Kórház és Rendelőintézet, Neurológiai Osztály, Budapest \\ ${ }^{5}$ Szent Imre Egyetemi Oktató Kórház, Angiológia, Budapest \\ ${ }^{6}$ Semmelweis Egyetem, Általános Orvostudományi Kar, Szemészeti Klinika, Budapest
}

\begin{abstract}
A tudomány jelenlegi állása szerint - csoportok összehasonlítására épülő matematikai-statisztikai eszközökkel - a leginkább hatékonynak és hatásosnak vélt kezelési módszerek szisztematikus elemzése mentén, a bizonyítékokon alapuló irányelveken nyugvó gyógyító munkát tekintjük követendőnek. A nyaki verőérszúkület ellátása esetén az utóbbi években elkészült mind a hazai, mind az európai irányelv, mindemellett a társszakmák irányelveiben is megjelentek kezelési javaslatok. Közleményünkben összehasonlítottuk a témában publikált magyar, angol, német és olasz nyelvű, valamint az európai társaságok által kiadott irányelveket. Az irányelvek alapelveikben hasonlóak, formailag és tartalmilag azonban jelentős (időnként egymásnak ellentmondani látszó) különbségeket találhatunk. Az ellentmondások három leggyakoribb oka: 1) az egyes irányelvek által kitüzött célok különbözősége, 2) az aszimptomatikus és szimptomatikus betegcsoport definíciói, valamint 3) az eltérő evidenciaszintek. Az irányelvek összevetése alapján a tünetes, szignifikáns nyaki verőérszúlkületek sebészi ellátása evidenciának tekinthető. A szimptomatikus nyaki verőérszúkület a definíció szerint ellenoldali cerebralis ischaemia okozta, tranziens vagy definitív plegia, paresis, aphasia és az azonos oldali arteria centralis retinae embolisatiója miatti amaurosis fugax. A tünetmentes nyaki veróérszúküuletek ellátása tekintetében az európai és a nemzeti irányelvek nem azonosak, ezen esetek terápiás döntése egyéni mérlegelést igényel. Tünetmentes, 70\%-os stenosis esetén vascularteam-konzílium javasolt.
\end{abstract}

Orv Hetil. 2020; 161(51): 2139-2145.

Kulcsszavak: nyaki verőérszúkület, stroke, cerebrovascularis betegség, irányelvek

\section{Differences in guidelines for patients with carotid artery stenosis in some European countries}

The correct practice is the one that is proven to be the most effective based on systematic statistical analyses of different treatment methods, and is applied according to evidence-based principles. In recent years, not only has the European Society of Vascular Surgery created a guideline about the management of supra-aortic steno-occlusive disease, but some nations' vascular surgical societies and related disciplines have also developed their own guidance. In this paper, the guidelines by the European societies on the clinical care of patients with carotid artery luminal narrowing is compared to national guidelines published in Hungarian, English, German, and Italian. Although the fundamental points of the guidelines are similar, there are some important differences among them both in presentation and in content; as a result, they sometimes appear to be contradictory. The three main sources of inconsistency are the various goals, the discrepancy in the definition of symptomatic and asymptomatic carotid artery stenosis, and the bias arising from the use of distinct evidence levels. A comparison of guidelines suggests that the treatment of symptomatic significant carotid artery stenosis with surgery can be considered evidence. Symptomatic carotid artery stenosis is defined as transient or definite plegia, paresis, aphasia due to cerebral ischemia, and monocular blindness 
caused by embolism in the central retinal artery. However, in the case of asymptomatic $70 \%$ or greater carotid artery stenosis, the guidelines are quite heterogeneous, and these patients require individual consideration and a vascular team decision is recommended.

Keywords: carotid artery stenosis, stroke, cerebrovascular disease, guidelines

Mihály Zs, Fontanini DM, Sándor ÁD, Dósa E, Lovas G, Kolossváry E, Kovács I, István L, Entz L, Sótonyi P Jr. [Differences in guidelines for patients with carotid artery stenosis in some European countries]. Orv Hetil. 2020; 161(51): 2139-2145

(Beérkezett: 2020. május 21.; elfogadva: 2020. július 14.)

\begin{abstract}
Rövidítések
ACC $=$ arteria carotis communis; ACI = arteria carotis interna; CAS $=$ carotis-angioplastica és sztentbeültetés CEA $=$ carotis endarteriectomia; CIRSE $=($ Cardiovascular and Interventional Radiological Society of Europe) Európai Cardiovascularis és Intervenciós Radiológiai Társaság; CTA $=($ computed tomography angiography) komputertomográfiás angiográfia; DGG = (Deutsche Gesellschaft für Gefaesschirurgie und Gefaessmedizin) Német Érsebészeti és Érgyógyászati Társaság; ESO = (European Stroke Organization) Európai Stroke Szervezet; ESVS $=$ (European Society of Vascular Surgery) Európai Érsebészeti Társaság; ISO = (Italian Stroke Organization) Olasz Stroke Szervezet; MAÉT = Magyar Angiológiai és Érsebészeti Társaság; MRA = mágnesesrezonancia-angiográfia MST $=$ Magyar Stroke Társaság; NICE = (National Institute for Health and Care Excellence) Az Egészség és Klinikai Kiválóság Nemzeti Intézete; OCT $=$ (optical coherence tomography) optikaikoherencia-tomográfia; SICVE $=($ Società Italiana di Chirurgia Vascolare ed Endovascolare) Olasz Ér- és Endovascularis Sebészeti Társaság; TIA = tranziens ischaemiás attak
\end{abstract}

A nyaki verőérszúkület ellátása multidiszciplináris feladat. Incidentálisan felfedezett, tünetmentes szúküulet esetén a családorvos, a belgyógyász, az angiológus, a kardiológus, az aneszteziológus, a neurológus és/vagy a szemész indíthatja el a további vizsgálatokat. A gyógyszeres terápia (thrombocytaaggregáció-gátló kezelés, sztatin) mellett hemodinamikailag 70\%-ot meghaladó szúkület esetén neurológiai esemény prevenciójaként revascularisatio jön szóba intervenciós radiológus vagy érsebész által. Multidiszciplináris döntés során dől el az invazív beavatkozás indikációja. Az arteria carotis interna (ACI) vagy az arteria carotis communis (ACC) tünetmentes, 60-99\%-os stenosisa esetén az 5 éves stroke-rizikó 5,1-11\% az 1995. évi első nagy vizsgálat alapján [1]. A jelentős bénulással járó stroke-ok nagy részében azonban nincs „bevezető” tranziens neurológiai deficit. Az egyik legnagyobb vizsgálatban a carotisendarteriectomián (CEA-n) átesett betegeknél feleannyi stroke volt 5 év alatt $(4,1 \% ; 6,9 \%$ a perioperatív stroke-arányt is beleszámítva), mint a konzervatív terápián lévőknél (10,9\%) [2].

A nyaki verőérszúküulet invazív ellátása történhet nyitott endarteriectomia során a szúkületet okozó plakk el- távolításával vagy intervenciós beavatkozás kapcsán sztentbeültetéssel (CAS), mely után minimum 1 hónapig kettős thrombocytaaggregáció-gátló kezelés javasolt. A nagy klinikai vizsgálatok alapján nyaki verőérszúlkület esetén a nyitott mútéttel összehasonlítva a beteg számára kisebb megterhelést jelentő sztentelésnek magasabb a periprocedurális stroke-kockázata $[3,4]$.

A neurológiai tünetek kapcsán felmerülő, releváns oldali nyaki verőérszúkuület esetén javasolt a sebészi revascularisatio. A neurológiai eseményt követően a mütét idejének eldöntése multidiszciplináris konzíliumot igényelhet a friss ischaemiás laesio nagyságának megítélése és a tünetek időbeli progressziója miatt. Az ACI-nak a macroangiopathia talaján kialakult szignifikáns szúküulete felelhet az összes ischaemiás stroke mintegy 20\%-áért [5]. A szignifikánsan szúkült (70\% feletti) tünetmentes és tünetes betegpopuláció stroke-rizikójában eltérések mutatkoznak. A neurológiai tünetet elszenvedett betegcsoportban az újabb stroke bekövetkezésének rizikója tranziens ischaemiás attak (TIA) után 7 napon belül 5,2\% egy átfogó metaanalízis szerint [6].

A hirtelen kialakuló átmeneti vagy végleges látásvesztés esetén, melynek hátterében állhat az arteria centralis retinae embolisatiója is, szemészeti kivizsgálás kapcsán kerülhet felfedezésre az azonos oldali nyaki verőérszúkület. Optikaikoherencia-tomográfiával (OCT) vizsgálva carotisstenosis esetén csökkent a chorioidea [7], továbbá csökkent idegrostréteg-vastagságot is leírtak, mely csökkenés korrelált a carotisszúkuulet mértékével [8]. Noha ezzel a módszerrel számszerúsíthető a mütét utáni keringésjavulás a retina kapillárisaiban, további vizsgálatok elvégzése szükséges annak eldöntésére, hogy az OCT hasznos lehet-e a carotisstenosis okozta keringéskárosodás kimutatásában és a műtéti eredményesség megítélésében.

Az irányelvek sokfélék. Egyes irányelvek egy adott kórkép ellátását vagy egy adott beavatkozás indikációs körét definiálják. Mások az evidenciaszintek osztályozásában térnek el. Jelentős különbségek mutatkoznak az irányelvet megfogalmazó társaságok társszakmákkal való konszenzusának mértékét illetően is. Ezeket a hazai és Európán belüli különbségeket foglaljuk össze publikációnkban a nyaki verőérszúkület invazív ellátásával kapcsolatban. 


\section{Célkitüzés}

Összefoglaló munkánk során az európai társaságok irányelveit, valamint az angol, német, olasz és magyar nyelvú érsebészeti, intervenciós radiológiai és neurológiai ajánlásokat tekintettük át a nyaki verőér-szúkületes betegek ellátásának tekintetében. A hazai gyakorlat összehasonlítása az európai irányelvekkel nemcsak a helyi ellátás sajátosságai okozta különbségeket, hanem az európai fősodorhoz igazodó hasonlóságokat is hivatott bemutatni. A kontinenstől mindig eltérő angol, a történelmi okokból hazánkban leginkább követett német és a külön utakon járó olasz irányelveknek a teljesség igénye nélküli bemutatásával könnyebben elhelyezhetjük a hazai útmutatókat az európai trendekben. A különböző társaságok által azonos témában kiadott irányelvek bemutatásával szeretnénk rávilágítani az együttmúködést lehetővé tevő azonosságokra és a zavart keltő ellentmondásokra.

Elemzésünk során a nyaki verőér-szúkületes betegek ellátásáról az ebben legszorosabban részt vevő neurológiai, érsebészeti és intervenciós radiológiai európai és nemzeti társaságok által 2006 és 2020 márciusa között hivatalosan közzétett irányelveket vizsgáltuk. Az egyes irányelvekben áttekintettük a tünetes és a tünetmentes nyaki verőérszúkület definícióját és a revascularisatio indikációjára tett ajánlásokat, illetve azok evidenciaszintjét.

\section{Európai irányelvek}

A három nagy európai társaság, úgymint az érsebészeti (ESVS: European Society of Vascular Surgery) [9], a neurológiai (ESO: European Stroke Organization) és az intervenciós radiológiai társaság (CIRSE: Cardiovascular and Interventional Radiological Society of Europe) [10] ajánlásait tekintettük át. Az ESO a 2019-ben megjelent új irányelvei közül a szekunder prevenció vonatkozásában a pitvarfibrilláció esetén javasolt antithromboticus kezeléseket tekintette át [11]. A 2020-as új összefoglaló az alvási apnoe és a stroke összefüggését vizsgálta [12]; a neurológiai tünetek hátterében álló, szignifikáns nyaki verőérszúkületről az újabb összefoglalók sem nyilatkoznak. A ma- gyar, német, angol és olasz nemzeti társaságok vagy egészségügyi ellátók által kiadott nemzeti irányelvek részletes ajánlásait szintén mélyrehatóan tanulmányoztuk.

\section{Az irányelvek formai különbségei}

Az egyes irányelvek frissítése országonként eltérő. Az 1 . ábra mutatja be egy számegyenesen a különböző irányelvek megjelenési évét. A legrégebbinek a CIRSE jelenleg átdolgozás alatt álló, 2006-os irányelve [10] számít, míg a legújabb a 2020 márciusában megjelent német irányelv (DGG: Deutsche Gesellschaft für Gefaesschirurgie und Gefaessmedizin) [13]. Az ESO új, 2019-re időzített irányelve egyelőre még nem érhető el. A NICE (National Institute for Health and Care Excellence) korábbi, 2008-as stroke-ellátási irányelvét 2019-ben átírták, valamint 2011-ben a tünetmentes és a tünetes nyaki verőérszúkuület intervenciós ellátásáról is külön irányelvet fogalmaztak meg [14-16]. Nagy-Britanniában és Írországban is a NICE-irányelvek alapján folyik a nyaki verőér-szúküuletes betegek ellátása. Az olasz neurológiai és érsebészeti társaság egy év különbséggel adta ki a SICVE (Società Italiana di Chirurgia Vascolare ed Endovascolare) és az ISO (Italian Stroke Organization) irányelveit [17, 18]. Az Egészségügyi Kollégium Érsebészeti és Angiológiai Tagozata és Tanácsa által a MAÉT-tal (Magyar Angiológiai és Érsebészeti Társaság) történt egyeztetés alapján került kiadásra egy egészségügyi irányelv 2016ban [19] (a továbbiakban MAÉT-irányelvként említjük). Az MST (Magyar Stroke Társaság) ellátási javaslata 2017-ben jelent meg [20] az Ideggyógyászati Szemlében.

Bizonyos országokban (Magyarország, Nagy-Britannia, Írország, Olaszország) egyes szakterületek határterületi kérdésekben saját irányelveket fogalmaztak meg, míg másokban (Németország, Ausztria) a társszakmákkal közös irányelveket adtak ki.

Az irányelvek a céljaikban is eltérnek. Míg az angolszász NICE-guideline egyes beavatkozások indikációját és kontraindikációját foglalja össze, addig német nyelvterületen (az európai irányelvekhez hasonlóan) az adott kórkép teljes körü ellátására vonatkozó részletes útmuta-

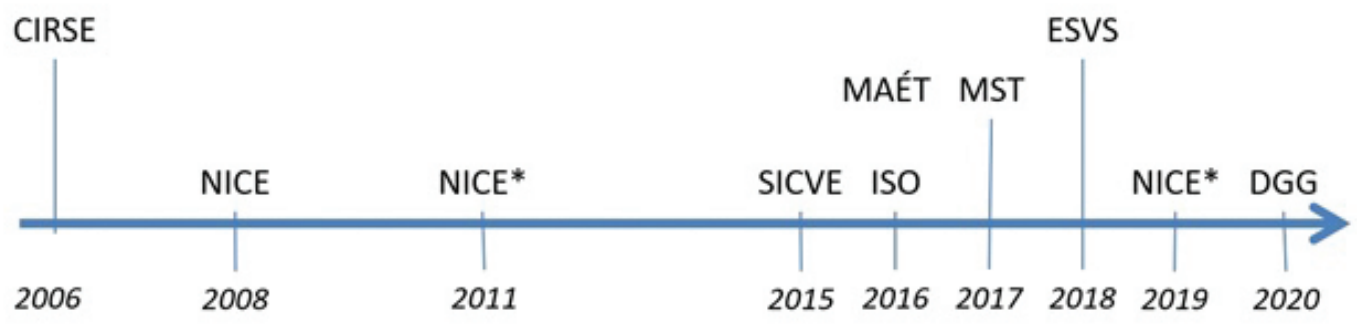

1. ábra $\quad$ A különböző szervezetek által a nyaki verőérszúkület ellátásáról kiadott irányelvek

CIRSE $=($ Cardiovascular and Interventional Radiological Society of Europe $)$ Európai Cardiovascularis és Intervenciós Radiológiai Társaság; DGG = (Deutsche Gesellschaft für Gefaesschirurgie und Gefaessmedizin) Német Érsebészeti és Érgyógyászati Társaság; ESVS = (European Society of Vascular Surgery) Európai Érsebészeti Társaság; ISO = (Italian Stroke Organization) Olasz Stroke Szervezet; MAÉT = Magyar Angiológiai és Érsebészeti Társaság; MST = Magyar Stroke Társaság; NICE = (National Institute for Health and Care Excellence) Az Egészség és Klinikai Kiválóság Nemzeti Intézete; SICVE = (Società Italiana di Chirurgia Vascolare ed Endovascolare $)$ Olasz Ér- és Endovascularis Sebészeti Társaság

*Guideline kiegészítésének kiadási időpontja. 
tót tartalmaznak az irányelvek. A különböző társaságok által megfogalmazott irányelvek célcsoportjai eltérőek, így például a neurológiai irányelvekben csak a tünetes betegcsoport ellátásáról fogalmazódik meg javaslat, az intervenciós radiológiai irányelvben pedig csak a CAS indikációi kerülnek részletezésre. Ebből adódóan tehát az egyes irányelvek alapján csak részben lehet nyilatkozni egy kórkép ellátásáról. Érdekes módon az olasz strokeirányelv (ISO) az egyetlen olyan neurológiai útmutató, amelyben a tünetmentes nyaki verőérszúkület ellátására is javaslatot tesznek.

1. táblázat |A különböző irányelvekben meghatározott definíciók összefoglalása

\begin{tabular}{|c|c|c|}
\hline Irányelv & $\begin{array}{l}\text { Tünetmentes nyaki } \\
\text { veróérszúkület }\end{array}$ & Tünetes nyaki verőérszúkület \\
\hline ESVS & $\begin{array}{l}\text { Aszimptomatikusnak } \\
\text { tekintendő minden olyan } \\
\text { beteg, akinél } 6 \text { hónapon } \\
\text { belül az arteria carotis } \\
\text { ellátási területének meg- } \\
\text { felelö tünet nem lépett fel }\end{array}$ & $\begin{array}{l}\text { Szimptomatikusnak } \\
\text { tekintendő minden olyan } \\
\text { beteg, akinél } 6 \text { hónapon } \\
\text { belül az arteria carotis } \\
\text { ellátási területének megfelelö } \\
\text { tünet lépett fel }\end{array}$ \\
\hline MAÉT & $\begin{array}{l}\text { UH-val, CTA-val, } \\
\text { MRA-val és/vagy DSA-val } \\
\text { kimutatható carotisbifurca- } \\
\text { tio és/vagy internaszúkü- } \\
\text { let, amely neurológiai vagy } \\
\text { azzal ekvivalens tünettel } \\
\text { nem járt }\end{array}$ & $\begin{array}{l}\text { UH-val, CTA-val, MRA-val } \\
\text { és/vagy DSA-val kimutat- } \\
\text { ható carotisbifurcatio és/ } \\
\text { vagy internaszúkület, } \\
\text { amely neurológiai vagy } \\
\text { azzal ekvivalens tünettel járt }\end{array}$ \\
\hline NICE & $\begin{array}{l}\text { A tünetmentes extracrania- } \\
\text { lis carotisstenosis általában } \\
\text { incidentálisan kerül } \\
\text { felismerésre a képalkotó } \\
\text { vizsgálatok során } \\
\text { (IPG338, IPG389) }\end{array}$ & $\begin{array}{l}\text { A stabil neurológiai állapotú } \\
\text { (nem mozgáskorlátozó } \\
\text { stroke-tól a TIA-ig } \\
\text { terjedően), a NASCET- } \\
\text { kritériumok szerint 50-99\% } \\
\text { közötti igazolt stenosissal } \\
\text { rendelkezők minősülnek } \\
\text { tünetesnek (IPG338, } \\
\text { IPG389). } \\
\text { Az atherosclerosis talaján } \\
\text { kialakult extracranialis } \\
\text { carotisstenosis TIA-t vagy } \\
\text { stroke-ot okozhat (NG128) }\end{array}$ \\
\hline DGG & $\begin{array}{l}\text { Az ESVS-guideline } \\
\text { definícióját vette át }\end{array}$ & $\begin{array}{l}\text { Az ESVS-guideline } \\
\text { definícióját vette át, azt } \\
\text { kiegészítve a releváns oldali } \\
\text { képalkotóval igazolt 'silent' } \\
\text { ischaemiás agyi infarktus } \\
\text { esetén is tünetesnek tekinti a } \\
\text { betegeket }\end{array}$ \\
\hline ISO & $\begin{array}{l}\text { A beteg tünetmentes, } \\
\text { vagy a neurológiai tünete } \\
3 \text { hónapnál régebbi }\end{array}$ & \\
\hline
\end{tabular}

CTA = komputertomográfiás angiográfia; DGG = (Deutsche Gesellschaft für Gefaesschirurgie und Gefaessmedizin) Német Érsebészeti és Érgyógyászati Társaság; DSA = digitális szubtrakciós angiográfia; ESVS = (European Society of Vascular Surgery) Európai Érsebészeti Társaság; ISO = (Italian Stroke Organization) Olasz Stroke Szervezet; MAÉT = Magyar Angiológiai és Érsebészeti Társaság; MRA = mágnesesrezonancia-angiográfia; NICE = (National Institute for Health and Care Excellence) Az Egészség és Klinikai Kiválóság Nemzeti Intézete; TIA = tranziens ischaemiás attak; $\mathrm{UH}=$ ultrahangvizsgálat

\section{Az irányelvek tartalmi különbségei}

Az 1. táblázat második és harmadik oszlopa összegzi az egyes irányelvekben megadott definíciókat és a tünetes, illetve a tünetmentes betegek ellátására tett ajánlásokat és azok indikációs szintjét. A 2. táblázat tartalmazza, hogy mely irányelvekben nem került meghatározásra az aszimptomatikus és a szimptomatikus betegség definíciója; pirossal jeleztük a hiányzó definíciót, míg zölddel az egyértelmúen definiált kórképet. Rendkívül lényeges különbség az egyes irányelvekben, hogy a tünetes és az aszimptomatikus nyaki veróérszúkület definíciója sok esetben nem azonos, amiból aztán indikációs különbségek is adódnak. A definíciók esetében különböző megfogalmazások születtek. Van, ahol a szúküulet mértékének megadására szolgáló konkrét képalkotás, illetve annak megállapítását leíró hivatkozás is meghatározásra került, máshol viszont csak a tünetesség [neurológiai tünet jelenléte vagy hiánya, illetve annak időtartama ( 6 vagy 3 hónapon belüli vagy azon túli) alapján aszimptomatikus vagy szimptomatikus egy beteg] került megfogalmazásra. Egyes irányelvek hivatkoznak az európai irányelvre, és részben átveszik az ott alkalmazott definíciókat (DGG), míg más országokban saját definíciókat alkalmaznak (NICE), de vannak olyan irányelvek is, amelyek egyáltalán nem adnak meg definíciót (CIRSE). Érdekes módon a DGG legújabb irányelve a szimptomatikusok közé

2. táblázat | Definíciók és evidenciaszintek

\begin{tabular}{|c|c|c|c|c|}
\hline \multirow[t]{2}{*}{ Irányelv } & \multicolumn{2}{|c|}{ Tünetmentes } & \multicolumn{2}{|l|}{ Tünetes } \\
\hline & Definíció & Evidenciaszint & Definíció & Evidenciaszint \\
\hline \multicolumn{5}{|l|}{ ESVS } \\
\hline \multicolumn{5}{|l|}{ CIRSE } \\
\hline \multicolumn{5}{|l|}{ ESO } \\
\hline \multicolumn{5}{|l|}{ MAÉT } \\
\hline \multicolumn{5}{|l|}{ MST } \\
\hline \multicolumn{5}{|l|}{ NICE } \\
\hline \multicolumn{5}{|l|}{ DGG } \\
\hline \multicolumn{5}{|l|}{ ISO } \\
\hline SICVE & & & & \\
\hline
\end{tabular}

CIRSE $=($ Cardiovascular and Interventional Radiological Society of Europe) Európai Cardiovascularis és Intervenciós Radiológiai Társaság; DGG $=($ Deutsche Gesellschaft für Gefaesschirurgie und Gefaessmedizin) Német Érsebészeti és Érgyógyászati Társaság; ESO = (European Stroke Organization) Európai Stroke Szervezet; ESVS = (European Society of Vascular Surgery) Európai Érsebészeti Társaság; ISO $=($ Italian Stroke Organization $)$ Olasz Stroke Szervezet; MAÉT = Magyar Angiológiai és Érsebészeti Társaság; MST = Magyar Stroke Társaság; NICE $=($ National Institute for Health and Care Excellence $)$ Az Egészség és Klinikai Kiválóság Nemzeti Intézete; SICVE = (Società Italiana di Chirurgia Vascolare ed Endovascolare) Olasz Ér- és Endovascularis Sebészeti Társaság

Magyarázat: zöld = egyértelmú kórképdefiníció, piros = guideline nem definiálja a kórképet, fehér $=$ a guideline adott kórképre nem tartalmaz ajánlást 
sorolja a képalkotással igazolt, releváns oldali 'silent' ischaemiás laesióval rendelkező betegeket is. Hazánkban a kórkép ellátásáról készült irányelvekben annak ellenére sincsenek összehangolva a definíciók, hogy egymáshoz képest viszonylag rövid időszakon belül jelent meg mindkét irányelv (MST, MAÉT).

Az alkalmazott evidenciaszinteket, illetve az ajánlások erősségét nem minden dokumentum tartalmazza, de ha mégis, akkor azok mindig a dokumentum elején találhatók. Erről összefoglaló a 2. táblázatban olvasható. Az evidenciaszintek és az ajánlások erősségei a legkülönbözőbb módokon kerültek meghatározásra. Ha az olvasó nem tanulmányozza ezeket a definíciókat, téves következtetésre juthat, hiszen például a magyar ajánlásban az erős = „grade 1.”, míg a német ajánlásban a "grade $\uparrow \uparrow$ ” jelzi az erôsebb evidenciát. Az olasz stroke-irányelv az erősen és gyengén ajánlott mellett az erôsen és gyengén ellenjavalt evidenciákat is megadja, ezzel szemben az olasz érsebészeti és endovascularis irányelv az ESVSirányelvben is alkalmazott standard evidenciaszinteket használja.

Abban konszenzus van, hogy tünetes nyaki verőérszúkületes betegek esetén rekonstrukció javasolt szekunder stroke-prevencióként; ez alól kivételt csak a Magyar Stroke Társaság képez, amely csak az akut stroke esetében felmerülő sebészi megoldást tárgyalja, azt is érintőlegesen, az intervenciós lehetőséget pedig meg sem említi. Mivel tünetmentes betegeknél a beavatkozás stroke-rizikója és az 5 éven belüli stroke-prevenció között elenyésző a különbség, az egyes szakterületek és országok között a terápiás javaslatok terén eltérések mutatkoznak. A legnagyobb különbségek az egyes szakterületek által javasolt indikációt és kontraindikációt jelentő állapotok esetén figyelhetők meg, amelyek hátterében sokszor az eltérőképpen definiált vagy nem is definiált fogalmak bújnak meg. A tandem laesiókról, amelyek tünetképző esetekben sikeres lízist követően kerülnek felfedezésre, kevés irányelv (NICE, DGG) nyilatkozik; ezekben az esetekben sztentelést javasolnak. Az ESVSirányelvben a tandem laesiók ellátásáról ajánlás nincs, csak a témába vágó irodalmat ismerteti konkrét ellátási javaslat megfogalmazása nélkül, illetve felveti, hogy az ilyen típusú laesiók esetén eltérő indikációs ajánlások lesznek szükségesek.

Eltérés mutatkozik az egyes beavatkozások (CEA versus CAS) favorizálásának mértékében is. A CIRSE 2006os irányelvében 60\% feletti tünetes szúkület esetén sztentelés javasolt, az aszimptomatikus betegeknél pedig ugyanazokat a kritériumokat említi, mint amelyek az ACST-tanulmányban vannak. 2006 óta számos publikáció jelent meg az extracranialis nyakiverőér-sztentelés kapcsán észlelt tünetmentes embolisatiókról, ezek az eredmények azonban az irányelv elkészítésekor még nem voltak ismertek. A 2018-as ESVS-irányelvben emiatt került a CAS másodlagos szerepbe, és vált alternatívájává a nyitott mütétnek nagy sebészi rizikó fennállása esetén. A NICE-guideline-ban, amely a 2019-es kiegészítésével a legfrissebbnek minősíthető tüneteket okozó nyaki verőérszúküulet esetén akut referálás javasolt sebészi rekonstrukció céljából; ebben az irányelvben a CAS még a CEA alternatívájaként sem merül fel. Ugyanez a guideline tünetmenteseknél csak speciális esetekben tartja indokoltnak az invazív beavatkozást. Az olasz érsebészeti és endovascularis irányelvben mind a tüneteseknél, mind a tünetmenteseknél a CEA favorizált a CAS helyett. A legrészletesebb az irányelvek közül a német nyelvú. Ez a guideline a definíciók tekintetében az európai irányelvet követi, és egyértelműen megfogalmazza (kiegészítve a szimptomatikus betegek körét a releváns oldali képalkotóval igazolt 'silent' ischaemiás laesio esetén), hogy mikor és milyen fokú ACI-szúkület esetén javasolt vagy képezi megfontolás tárgyát a beavatkozás, illetve részletes indikációs listát is tartalmaz arról, hogy mely esetben alkalmazható a CAS a CEA-val szemben. Új irányelvükben újdonságként jelenik meg egy részletes lista arról, hogy mely képalkotással igazolt állapotok esetén tekintendő az aszimptomatikus carotis stenosis magas strokerizikójúnak. Ezeknél a betegeknél javasolt grade $\uparrow, 1$. evidenciaszinttel a CEA elvégzése. A magyar érsebészeti irányelv többnyire az európaival azonos ajánlásokat fogalmaz meg; lényeges eltérés csak a definíciók terén mutatkozik, ahol nem használja a 6 hónapon belüli határnapot a tünetes és a tünetmentes esetek elkülönítésére.

\section{Megbeszélés}

Léteznek nemzetközi ajánlások a klinikai gyakorlati irányelvek standardizálására annak érdekében, hogy garantálják a minőségi mutatókat, és javítsák az alkalmazhatóságot. Ezen ajánlás keretében egy 18 pontos listát fogalmaztak meg azért, hogy az elkészülő irányelvek átfogóbbá váljanak [22]. Az amerikai érsebészeti társaság 2011-ben adott ki közleményt azzal a céllal, hogy segítsék a klinikusokat a döntéshozatalhoz szükséges klinikai irányelveik fejlesztésével [23]. Már a nyaki verőérszúkületre vonatkozó, 2008-as amerikai irányelv összeállításakor is hangsúlyt fektettek arra, hogy ne csak érsebész, hanem endovascularis szakember is részt vegyen annak kialakításában [24].

Eltérés figyelhető meg a különböző irányelvek publikációjának módjában is. Míg a nagy európai társaságok vezető szaklapokban publikálják irányelveiket (ESVS, ESO) $[9,11,12]$, addig a kisebb nemzeti társaságok (MAÉT, DGG, NICE, ISO, SCIVE) fenntartó vagy egészségügyi minőségbiztosítást végző szakfelügyeletek honlapján jelentetik meg irányelveiket [10, 13-19].

Az olyan speciális, multidiszciplináris döntést igénylő kórképek esetén, mint amilyen a nyaki verőérszúkület is, rendkívül fontos, hogy a különböző diszciplínák közös irányelv alapján tudjanak döntésre jutni, és ne egymással konkuráló vagy éppen egymásnak ellentmondó útmutatók lobogtatásává váljon egy multidiszciplináris megbeszélés. Fontos továbbá az is, hogy határterületi kérdésben a más diszciplínák által készített irányelveket is 
elfogadjuk, és támaszkodni tudjunk rájuk. Például szimptomatikus ACI-szúkületnek számít az azonos oldali arteria centralis retinae embolisatiója kapcsán létrejövó ischaemia is, de érdekes módon a szemészeti társaságok ezzel kapcsolatban nem foglalnak állást saját irányelveikben, a multidiszciplináris együttmúködésben készült irányelvek (DGG, MAÉT) megalkotásához pedig nem kérték fel őket $[13,18]$. Ezzel szemben a neurológiai társaságok egy része a stroke-irányelvekben (ISO, MST) $[17,19]$ foglalkozik a határterületi kérdéskörrel, és az érsebészeti irányelvek jóváhagyói között is ott vannak a neurológusok.

Felmerül a kérdés, hogy érdemes-e nemzeti irányelveket létrehozni, nem egyszerúbb-e vagy hatékonyabb-e csupán az európai társaságok által megfogalmazott vezérfonalakat követni. 2012-ben - nyolc európai ország által a VASCUNET-adatbázisba szolgáltatott adatok alapján - az esetek 92\%-ában az akkor érvényes európai irányelv ajánlása szerint határozták meg a mütét indikációját (hazánkban az esetek 81\%-ában) [24]. A legnagyobb eltérés Olaszországban adódott, ahol csak az esetek 70,3\%-ában történt beavatkozás az ESVS-ajánlás indikációs körébe tartozó betegeknél [2]. Egy 2015-ben megjelent metaanalízisben 23 ország 6 nyelven íródott irányelvét tekintették át a tünetmentes és a tünetes nyaki verőérszúkület kezeléséről. Eredményeik kapcsán megjegyezték, hogy a különböző módokon összefoglalt ajánlások és evidenciák nem egységesek, így az irányelvek összehasonlítása és interpretálása nehézségekbe ütközik [24]. Ennek kapcsán felmerülő probléma, hogy az egyes irányelvek különbözősége megnehezíti a nemzetek által szolgáltatott adatok retrospektív összehasonlítását, illetve a nagy, közös adatbázisok létrejöttével történő eredmények interpretációját. A nyaki verőérszúküulet ellátásának különböző országokban megvalósuló gyakorlatát összehasonlító tanulmányban az aszimptomatikus és a szimptomatikus betegek kezelésében jelentős eltérések adódtak az országok között [25]. Az olaszországi adatokban az aszimptomatikus betegek aránya 73\%-os a nyakiverőér-mútéten átesettek között (ez volt a legmagasabb aszimptomatikus arány) [25], ami magyarázható lehet azzal a ténnyel is, hogy az olasz útmutatóban csak 3 hónapon belüli neurológiai esemény esetén beszélnek tünetes nyaki verőérszúkületről.

A MAÉT-irányelv ajánlása alapján tünetmentes, képalkotó diagnosztikával igazolt 70\% feletti nyaki verőérszükület esetén a carotisrevascularisatióról a kísérô betegségek, a várható élettartam és az egyéb egyéni tényezők alapos mérlegelése alapján vascularteam dönt. A 11. ajánlás a és b alpontjában részletezi az irányelv azt, hogy emelkedett stroke-rizikó esetén (Al evidencia) elsősorban CEA javasolt, CAS csak magas cardiovascularis rizikó esetén jön szóba (B2 evidencia). A 16. ajánlás magas mútéti rizikó esetén (B2 evidencia) konzervatív kezelést javasol [19]. Ezen részletek ismeretében a hazai ajánlás egybehangzó az ESVS-ajánlással. A hazai ajánlás abban is megegyezik az ESVS iránymutatásával, hogy a mútét indikációját multidiszciplináris team állítsa fel.

Akut stroke kivizsgálása során igazolódott releváns nyaki verőérszúküulet esetén az MST („Egészségügyi szakmai irányelv az akut ischaemiás stroke diagnosztikájáról és kezeléséről”) gyenge evidenciaszint mellett (IIb osztály, B szint) nem javasolja az akut rekonstrukciót, ami némiképp ellentmond az összes többi, korábban tárgyalt irányelvnek [20]. Jelenleg is napirenden lévő téma érsebészek körében a szimptomatikus betegek sürgős rekonstrukciójának pontos időzítése (48 órán belül versus a 2. és a 14. nap között) [10]. A MAÉT- és az ESVSirányelvben nemzetközi klinikai vizsgálatok által igazolt, I. osztályú A szintű evidencia alapján javasolják a sürgető revascularisatiót szekunder stroke-prevenció céljából a releváns oldali neurológiai tüneteket vagy azonos oldali átmeneti vagy végleges látásvesztést okozó nyaki verőérszúkület esetén $[10,18]$; a sürgető műtét pontos időpontjáról azonban nem nyilatkozik ajánlás szintjén az ESVS sem. Tüneteket okozó nyaki verőérszúkület esetén a beavatkozás indikációja egyértelmú, azonban az időzítés és a beavatkozás típusa (nyitott mútét vagy sztentimplantáció) minden betegnél individuálisan az anatómiának, az agyi ischaemia kiterjedésének, az anamnesztikus adatoknak (nyaki besugárzás, korábbi nyakiverőér-mútét) és a cardiovascularis rizikó statusának a figyelembevételével multidiszciplináris team döntése kell, hogy legyen.

\section{Következtetések}

A kiadott irányelvek megkönnyítik a klinikai rutin helyi kialakítását, és egyes ritkább eseteknél megerősítésül szolgálnak a klinikusnak a döntéshozatalban. A nemzeti és az európai irányelvek különbségei első olvasásra marginálisnak tûnnek, azonban az eltérő evidenciaszintek és a definíciók különbözősége az egyes nemzetek klinikai rutinjában jelentős különbségeket okoz. Így az adatok összehasonlítása és interpretációja esetén a következtetések levonása nehezített. Az országon belüli szakmai kollégiumok ajánlásainak súrlódása megnehezíti a multidiszciplináris teamek múködését. Rendkívül fontos a helyi és a nemzeti irányelvek ismerete és ennek fényében az európai útmutatók értő olvasása (a definíciók és az evidenciaszintek szem előtt tartásával), ami a későbbi útmutatók készítéséhez adhat támpontot.

A magyarországi protokoll és az európai irányelv alapján javasolnánk a 6 hónapon belüli tünetes (azonos oldali látásvesztés, ellenoldali plegia, paresis és aphasia) betegek $60 \%$ feletti nyaki verőérszúküuletének 2 héten belüli rekonstrukcióját. A tünetmentes, incidentálisan felfedezett, 70\% feletti (CTA-val vagy MRA-val igazolt) szúkület esetén pedig - amennyiben társbetegségek miatt nem emelkedett a perioperatív rizikó - elsősorban elektív sebészi nyakiverőér-rekonstrukciót, míg emelkedett 
kockázat esetén sztentimplantációt vagy optimális gyógyszeres kezelést (thrombocytaaggregáció-gátlást és sztatinkezelést) javasolunk.

Anyagi támogatás: A közlemény megírása a Nemzeti Kutatási, Fejlesztési és Innovációs Hivatal K_16-os pályázatából (NKFIH K 129277) anyagi támogatásban részesült.

Szerzői munkamegosztás: Tervezés, adatgyưjtés, elemzés, a kézirat szövegezése: M. Zs., F. D. M., S. P. jr. A kézirat átnézése, javítása, jóváhagyása: M. Zs., F. D. M., S. Á. D., L. G., D. E., K. E., E. L., S. P. jr., K. I., I. L. A cikk végleges változatát valamennyi szerző elolvasta és jóváhagyta.

Érdekeltségek: A szerzőknek nincsenek érdekeltségeik.

\section{Irodalom}

[1] Endarterectomy for asymptomatic carotid artery stenosis. Executive Committee for the Asymptomatic Carotid Atherosclerosis Study. JAMA 1995; 273: 1421-1428.

[2] Halliday A, Harrison M, Hayter E, et al. 10-year stroke prevention after successful carotid endarterectomy for asymptomatic stenosis (ACST-1): a multicentre randomised trial. Lancet 2010; 376: 1074-1084.

[3] Silver FL, Mackey A, Clark WM, et al. Safety of stenting and endarterectomy by symptomatic status in the Carotid Revascularization Endarterectomy Versus Stenting Trial (CREST). Stroke $2011 ; 42$ : 675-680.

[4] Rosenfield K, Matsumura JS, Chaturvedi S, et al. Randomized trial of stent versus surgery for asymptomatic carotid stenosis. $\mathrm{N}$ Engl J Med. 2016; 374: 1011-1020.

[5] Grau AJ, Weimar C, Buggle F, et al. Risk factors, outcome, and treatment in subtypes of ischemic stroke: the German stroke data bank. Stroke 2001; 32: 2559-2566.

[6] Giles MF, Rothwell PM. Risk of stroke early after transient ischaemic attack: a systematic review and meta-analysis. Lancet Neurol. 2007; 6: 1063-1072.

[7] Sayin N, Kara N, Uzun F, et al. A quantitative evaluation of the posterior segment of the eye using spectral-domain optical coherence tomography in carotid artery stenosis: a pilot study. Ophthalmic Surg Lasers Imaging Retina 2015; 46: 180-185.

[8] Wang D, Li Y, Zhou Y, et al. Asymptomatic carotid artery stenosis and retinal nerve fiber layer thickness. A community-based, observational study. PLoS ONE 2017; 11: e0177277.

[9] Naylor AR, Ricco JB, de Borst GJ, et al. Editor's choice - Management of atherosclerotic carotid and vertebral artery disease: 2017 Clinical Practice Guidelines of the European Society for Vascular Surgery (ESVS). Eur J Vasc Endovasc Surg. 2018; 55: 3-81.

[10] McDonald S, Cleveland TJ, Gaines PA. Quality assurance guidelines for the performance of carotid stenting: European Standards adopted and modified by CIRSE in cooperation with the Society of Interventional Radiology (SIR) Standards of Practice Committee. Available from: https://www.cirse.org/wp-content/uploads/2018/11/2006_Performance-of-Carotid-Stenting_McDonald.pdf [accessed: May 20, 2020].

[11] Klijn CJ, Paciaroni M, Berge E, et al. Antithrombotic treatment for secondary prevention of stroke and other thromboembolic events in patients with stroke or transient ischemic attack and non-valvular atrial fibrillation: a European Stroke Organisation guideline. Eur Stroke J. 2019; 4: 198-223.

[12] Bassetti CL, Randerath W, Vignatelli L, et al. EAN/ERS/ESO/ ESRS statement on the impact of sleep disorders on risk and outcome of stroke. Eur J Neurol. 2020; 27: 1117-1136.

[13] Eckstein HH, Kühnl A, Berkefeld J, et al. S3 - Extracranial carotid artery stenosis treatment guideline. 3. Februar 2020 [S3 Leitlinie zur Diagnostik, Therapie und Nachsorge der extracraniellen Carotisstenose. 3. Februar 2020] Available from: https:// www.awmf.org/leitlinien/aktuelle-leitlinien/ll-liste/deutschegesellschaft-fuer-gefaesschirurgie.html [accessed: May 20, 2020]. [German]

[14] Stroke and transient ischaemic attack in over 16s: diagnosis and initial management. NICE guideline [NG128]. Published date: 01 May 2019. Available from: https://www.nice.org.uk/guidance/ng128 [accessed: May 20, 2020].

[15] NICE guideline. Carotid artery stent placement for asymptomatic extracranial carotid stenosis. Interventional procedures guidance [IPG388]. Published date: 27 April 2011. Available from: https://www.nice.org.uk/guidance/ipg388 [accessed: May 20, 2020].

[16] NICE guideline. Carotid artery stent placement for symptomatic extracranial carotid stenosis. Interventional procedures guidance [IPG389]. Published date: 27 April 2011. Available from: https://www.nice.org.uk/guidance/ipg389 [accessed: May 20, 2020].

[17] ISO, Stroke prevention guideline. [SPREAD VIII. edizione: Ictus cerebrale: linee guida italiane di prevenzione e trattamento. Raccomandazioni e Sintesi Stesura del 21 luglio 2016.] Available from: https://www.iso-stroke.it/?page_id=200 [accessed: May 20, 2020]. [Italian]

[18] Setacci C, Argenteri A, Chremonesi A, et al. Guideline for disease of carotid artery. [Linee Guida SICVE 3. Patologia carotidea.] 2015. Available from: https://www.sicve.it/consensi-e-lineeguida/ [accessed: May 20, 2020]. [Italian]

[19] Extracranial carotid artery stenosis invasive treatment guideline. [Egészségügyi szakmai irányelv $000750-\mathrm{Az}$ extracranialis artéria carotis interna szúkuület invazív ellátásáról.] 2018. http:// neak.gov.hu/felso_menu/szakmai_oldalak/szakmai_iranyelvek [accessed: May 20, 2020]. [Hungarian]

[20] Acute stroke diagnostic and treatment guideline. [A Magyar Stroke Társaság és az Egészségügyi Szakmai Kollégium Neurológiai Tagozata. Egészségügyi szakmai irányelv az akut ischaemiás stroke diagnosztikájáról és kezeléséról.] 2017. https://www.doki. net/tarsasag/stroke/info.aspx?sp=56\&web_id= [Hungarian ]

[21] Shiffman RN, Shekelle P, Overhage JM, et al. Standardized reporting of clinical practice guidelines: a proposal from the Conference on Guideline Standardization. Ann Intern Med. 2003; 139: 493-498.

[22] Murad MH, Montori VM, Sidawy AN, et al. Guideline methodology of the Society for Vascular Surgery including the experience with the GRADE framework. J Vasc Surg. 2011; 53: 1375-1380.

[23] Vikatmaa P, Mitchell D, Jensen LP, et al. Variation in clinical practice in carotid surgery in nine countries 2005-2010. Lessons from VASCUNET and recommendations for the future of national clinical audit. Eur J Vasc Endovasc Surg. 2012; 44: 11-17.

[24] Abbott AL, Paraskevas KI, Kakkos SK, et al. Systematic review of guidelines for the management of asymptomatic and symptomatic carotid stenosis. Stroke 2015; 46: 3288-3301.

[25] Venermo M, Wang G, Sedrakyan A, et al. Carotid stenosis treatment: variation in international practice patterns. Eur J Vasc Endovasc Surg. 2017; 53: 511-519.

(Mihály Zsuzsanna dr., Budapest, Városmajor u. 68., 1122 e-mail: zsuzsannamihaly@gmail.com)

A cikk a Creative Commons Attribution 4.0 International License (https://creativecommons.org/licenses/by/4.0/) feltételei szerint publikált Open Access közlemény. (SID_1) 